\title{
SISTEM INFORMASI PERPUSTAKAAN BERBASIS WEB MENGGUNAKAN BARCODE PADA SMP NEGERI 11 BANJARMASIN
}

\author{
Hayati Noor $^{1)}$, FakhrianiEkawati ${ }^{2)}$, DwiAgungWibowo ${ }^{3)}$ \\ ${ }^{1}$ Fakultas Teknologi Informasi Universitas Islam Kalimantan Muhammad Arsyad Al Banjari Banjarmasin \\ email: Adhienk.athie@gmail.com \\ ${ }^{2}$ Fakultas Teknologi Informasi Universitas Islam Kalimantan Muhammad Arsyad Al Banjari Banjarmasin \\ email: fakhrianiekawati@gmail.com \\ ${ }^{3}$ Fakultas Teknologi Informasi Universitas Islam Kalimantan Muhammad Arsyad Al Banjari Banjarmasin \\ email: agungfti@gmail.com
}

\begin{abstract}
Abstrak
Perpustakaan yang ada di sekolah merupakan sebuah wadah yang digunakan oleh siswa untuk mencari referensi dan memperoleh berbagai informasi.Dalam perpustakaan terdapat pengelolaan terhadap data buku, data anggota, serta pengelolaan transaksi peminjaman dan pengembalian buku. Dari perancangan system informasi perpustakaan ini mempunyai tujuan untuk menyelesaikan permasalahan sistem manual yang masih ada di perpustakaan SMP Negeri 11 Banjarmasin, merancang, membangun, dan kemudian mengimplementasikan Sistem Informasi Perpustakaan Berbasis Web Menggunakan Barcode pada SMP Negeri 11 Banjarmasin. Jenis penelitian yang peneliti gunakan merupakan jenis penelitian terapan, yaitu jenis penelitian yang mengembangkan dari penelitian yang telah ada kedalam aplikasi baru.Untuk teknik pengambilan data yang digunakan terdiri atas observasi (observation), wawancara (interview), dan studi pustaka.Sedangkan dari segi analisis sistem yang digunakanya itu analisis PIECES (Performance, Information, Economic, Control, Efficiency, dan Services).Adapun Hasil penelitian ini menunjukkan Sistem Informasi Perpustakaan Berbasis Web Menggunakan Barcode pada SMP Negeri 11 Banjarmasin yang memberikan kemudahan dan kecepatan dalam pengolahan data perpustakaan berbasis Web dengan system komputerisasi sehingga meningkatkan pelayanan perpustakaan
\end{abstract}

Kata Kunci :Perpustakaan, SistemInformasi, Web, PIECES

\section{PENDAHULUN}

\subsection{Latar Belakang}

Bagi dunia pendidikan perpustakaan adalah penyedia ilmu pengetahuan dan informasi yang mempunyai peranan yang signifikan terhadap para siswa sebagai penggunanya. Perpustakaan biasanya difungsikan oleh pengunjung sebagai media untuk mencari referensi dan memperoleh informasi.

Termasuk SMP Negeri 11 Banjarmasin yang juga menyediakan perpustakaan sebagai taman baca bagi para siswanya. Akan tetapi pengelolaan data perpustakaannya masih secara manual, sehingga akan menimbulkan masalah, mulai dari lamanya pencatatan data-data perpustakaan, pencatatan tanggal peminjaman dan pengembalian, serta pembuatan kartu anggota perpustakaan. Dari masalah ini menimbulkan terlambatnya pembuatan laporan yang berkaitan dengan lambatnya informasi, sehingga akan sulit untuk dijadikan acuan pengambilan keputusan atau tindakan yang diperlukan untuk kemajuan perpustakaan. Faktor inilah yang mendukung pentingnya penggunaan komputer dalam mengolah data di perpustakaan. Diperlukannya sebuah sistem informasi perpustakaan untuk menunjang 
kinerja pada perpustakaan itu sendiri yang berbasis komputerisasi.

\subsection{Rumusan Masalah}

Berdasarkan latar belakang diatas, maka perlu suatu langkah untuk mempermudah pengelolaan perpustakaan pada smp 11 banjarmasin tersebut .rumusan masalah yang akan diuraikan pada penelitian ini yaitu bagaimanakah aplikasi Sistem Informasi Perpustakaan Berbasis Web Menggunakan Barcode pada SMP Negeri 11 Banjarmasin ini dapat membantu setiap kegiatan ataupun administrasi pada perpustakaan tersebut dengan baik.

\subsection{Tujuan dan Target Luaran}

Tujuan dari penelitian ini adalah membuat suatu Perancangan Aplikasi Sistem Informasi Perpustakaan Berbasis Web Menggunakan Barcode pada SMP Negeri 11 Banjarmasin. .Adapun Manfaat yang diharapkan yaitu dengan dibuatnya aplikasi ini diharapkan dapat mempermudah pengelolaan ataupun sistem administrasi pada perpustakaan smp 11 banjarmasin.

Target luaran yang ingin dicapai oleh peneliti adalah Penelitian ini bisa masuk Prosiding Jurnal UNISKA.

\section{Barcode}

Pengenalan kode batang adalah suatu teknik yang tergantung pada strip-strip hitam putih Universal Product Code (UPC) yang ditempelkan pada kebanyakan barang di pasar swalayan, buku, dan majalah (Amsyah, 2005, p. 227).

Barcode merupakan label yang dikeluarkan oleh perusahaan yang dapat mempermudah pembeli untuk mengetahui harga melalui sebuah mesin pembaca(Royan, 2005, p. 85)

Ada beberapa manfaat dari adanya barcode, yaitu antara lain :

1. Proses dari input data lebih cepat, hal ini karena barcode scanner dapat membaca dan merekam data jauh lebih ceoat dari pada dengan melakukan proses input data secara manual.
2. Proses input data yang lebih tepat, karena teknologi barcode memiliki akurasi serta ketilitian yang tinggi.

3. Hemat biaya, karena bisa menghindari kerugian dari kesalahan-kesalahan pencatatan data serta dapat mengurangi pekerjaan yang dilakukan secara manual secara berulang.

4. Meningkatnya kinerja manajemen, dikarenakan dengan data yang lebih cepat, tepat serta akurat maka dalam pengambilan keputusan yang dilakukan oleh manajemen akan jadi jauh lebuh baik dan tepat yang akhirnya akan sangat berpengaruh dalam menetapkan kebijakan pada perusahaan.

5. Kemampuan bersaing dengan perusahaan saingan lebih terjaga.

\section{METODE PENELITIAN}

Untuk memperoleh data yang diperlukan dalam penyusunan penelitian ini dengan menggunakan metode pengumpulan data sebagai berikut:
a. Wawancara atau interview
b. Pengamatan Langsung atau Observasi.

Tujuan pembuatannya adalah membuat suatu Perancangan Aplikasi untuk pengelolaan perpustakaan SMPN 11 Banjarmasin. sehingga dapat membantu setiap kegiatan registrasi dan administrasi perpustakaan dengan baik.

Langkah yang digunakan dalam penelitian ini adalah merancang dan membuat sistem aplikasi yang berisi database sebagai media penyimpanan. Berikut rincian langkah-langkah yang dilakukan dalam penelitian ini :

1. Pengajuan proposal

2. Mengakaji ulang teori yang sudah disetujui dan mulai melakukan pengumpulan data premier serta data sekunder untuk penelitian objek lebih lanjut.

3. Melakukan Pengolahan data-data yang sudah dikumpulkan serta menganalisa kebutuhan system untuk mendukung 
pembuatan aplikasi yang sudah menjadi tujuan.

4. Membuat rancangan serta mempersiapkan Pembuatan Aplikasi Sistem Informasi Perpustakaan Berbasis Web Menggunakan Barcode pada SMP Negeri 11 Banjarmasin.

5. Melakukan testing dan implementasi system serta Pengujian Alat

6. Melakukan revisi atau perbaikan baik program atau pun alat jika diperlukan

7. Pembuatan laporan penelitan

8. Mengikuti Seminar hasil penelitian

Metode penelitian dalam hal ini meliputi perancangan yang kemudian diwujudkan dengan menggunakan Software NetBeans IDE. Untuk analisa Kebutuhan Sistem Dalam Desain Aplikasi Sistem Informasi Perpustakaan Berbasis Web Menggunakan Barcode pada SMP Negeri 11 Banjarmasin yang akan dibuat nanti diharapkan dapat menyelesaikan masalah-masalah yang dihadapi. Dengan demikian akan membuat beberapa menu guna mempermudah dalam sistem kerja dan agar dapat melangsungkan pengetesan secara baik, serta kebutuhan yang sesuai dengan keinginan.

Adapun beberapa hardware dan software yang digunakan adalah

1. Perangkat Keras (hardware)

a. Laptop Acer Aspire ES 14

b. Printer untuk mencetak laporan

c. Handphone Android termasuk dan kamera untuk dokumentasi

GPS

2. Perangkat Lunak (software)

a. Microsoft Office 2016

b. Tools barcode.

\section{HASIL DAN PEMBAHASAN}

\section{Analisis Kinerja (Performance Analysis)}

Analisisi kinerja diukur dengan jumlah layanan dan waktu tanggap. Jumlah layanan adalah jumlah pekerjaan yang bisa diselesaikan selama jangka waktu tertentu. Waktu tanggap adalah keterlambatan ratarata antara satu transaksi dengan tanggapan yang diberikan kepada transaksi tersebut.

\begin{tabular}{|c|c|}
\hline & Sistem Baru \\
\hline 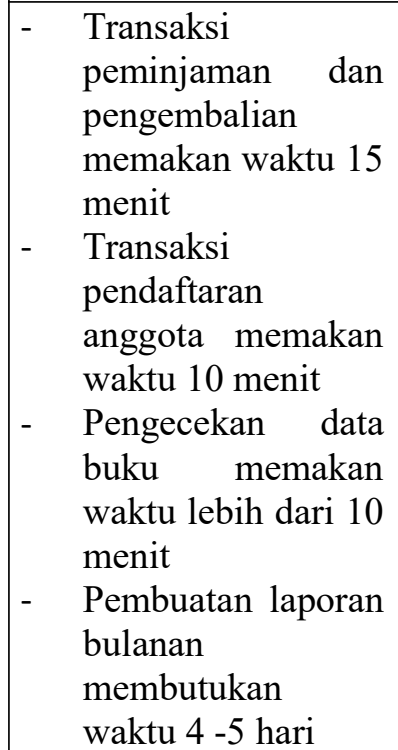 & 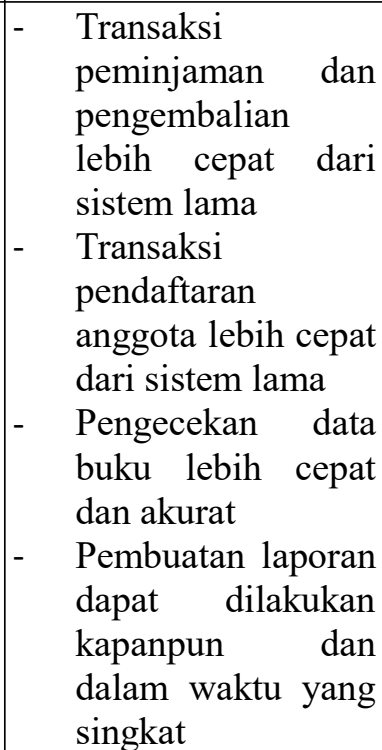 \\
\hline
\end{tabular}

\section{Analisis Informasi (Information Analysis)}

Informasi merupakan komoditas krusial bagi pengguna akhir. Informasi juga dapat merupakan fokus dari suatu batasan atau kebijakan. Sementara analisis informasi memeriksa output sistem, analisis data meneliti data yang tersimpan dalam sebuah sistem.

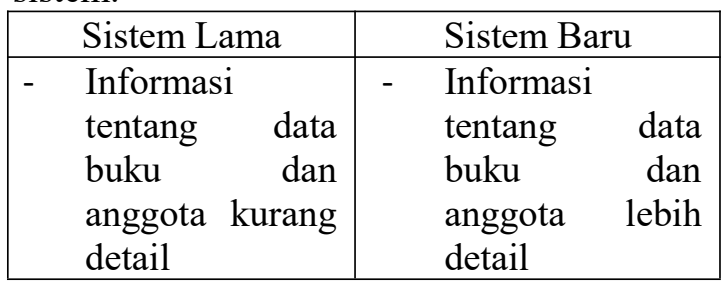

\section{Perancangan Flowchart}

Pada proses peminjaman sistem informasi perpustakaan dimulai dengan pencarian buku oleh anggota dengan meminta kepada petugas perpustakaan untuk mencarikan buku dengan menggunakan sistem pencarian, kemudian jika buku ingin dipinjam oleh anggota, pihak petugas perpustakaan akan menginputkan transaksi peminjaman pada sistem kemudian menyerahkannya kembali kepada peminjam. Sedangkan untuk proses pengembalian, peminjam menyerahkan buku yang dipinjam kepada petugas perpustakaan yang selanjutnya dilakukan pengecekan buku dan penginputan pengembalian oleh pihak petugas. Jika terjadi keterlambatan 
pengembalian, oleh sistem akan melakukan perhitungan denda sesuai dengan ketentuan.

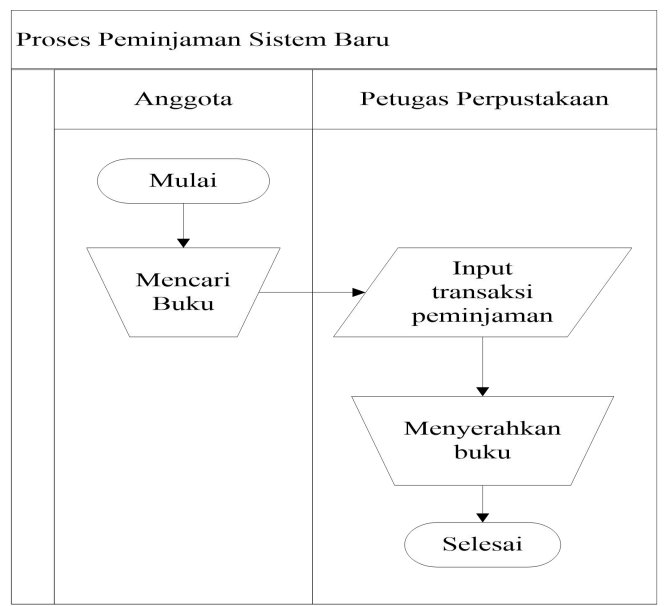

Flowchart Proses Peminjaman Sistem Baru

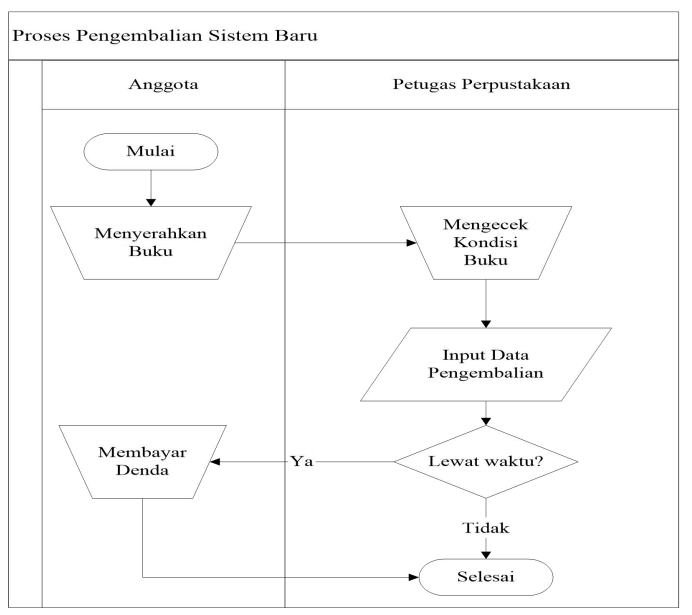

Flowchart Proses Pengembalian Sistem Baru

\section{Data Flow Diagram}

DFD adalah suatu model logika data atau proses yang menggambarkan dari mana asal data dan kemana tujuan data yang keluar dari sistem, dimana data disimpan, proses apa yang menghasilkan data tersebut dan interaksi antara data yang tersimpan dan proses yang dikenakan pada data tersebut.

\section{Diagram Konteks}

Diagram konteks merupakan tahap awal dari perancangan sistem dengan memuat hanya satu proses yang menunjukan sistem secara keseluruhan. Diagram konteks sistem informasi perpustakaan pada SMP Negeri 11 Banjarmasin yaitu sebagai berikut :

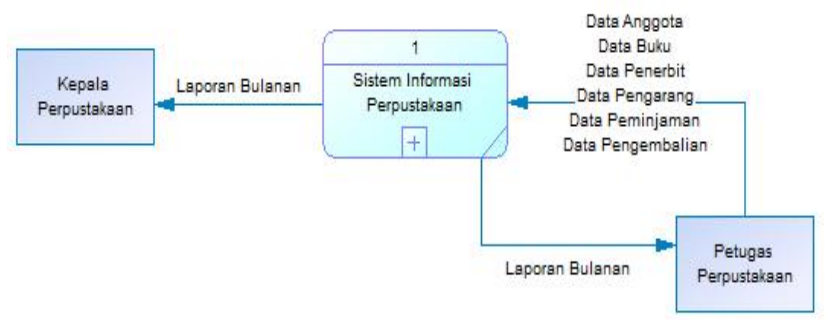

Diagram Konteks

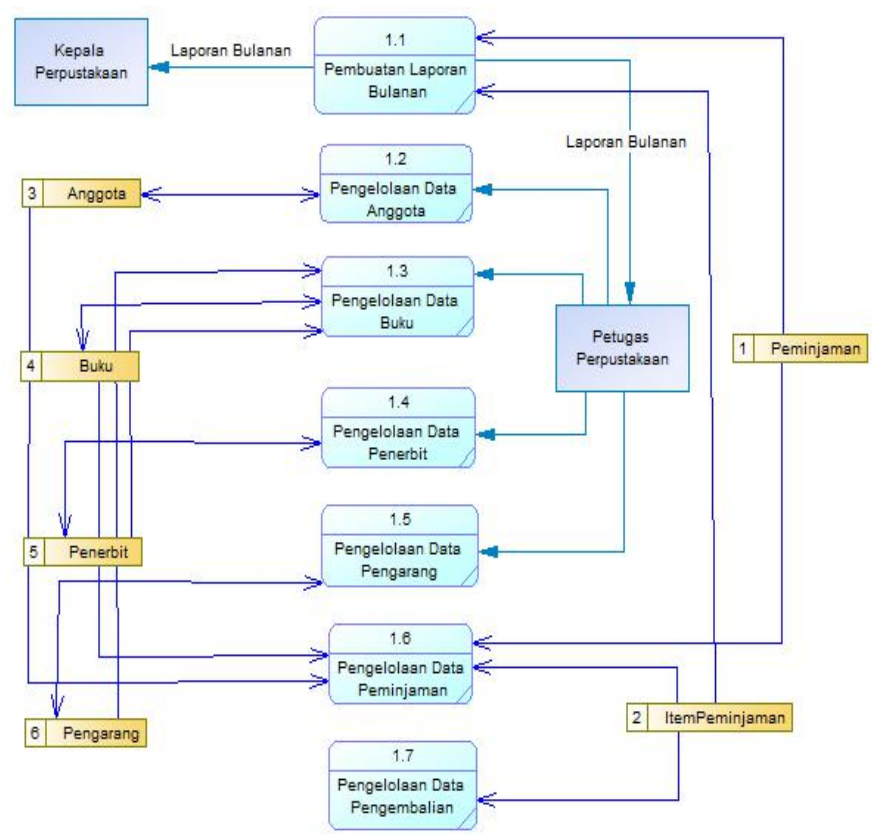

DFD Level 1

\section{Halaman Utama / Pencarian Informasi \\ Buku}

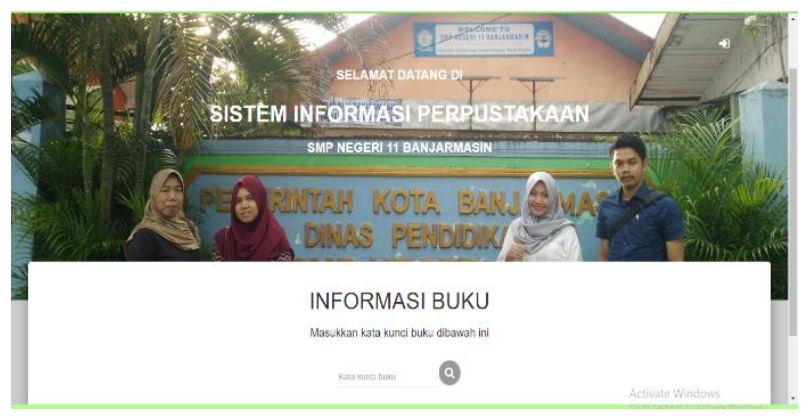

Halaman Login Admin

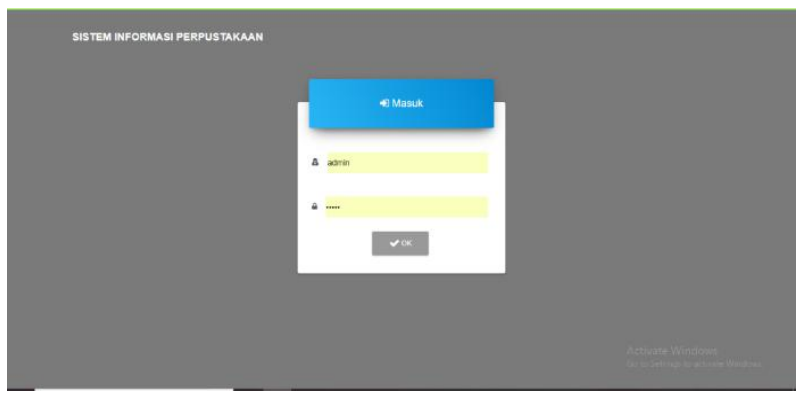


Halaman Beranda

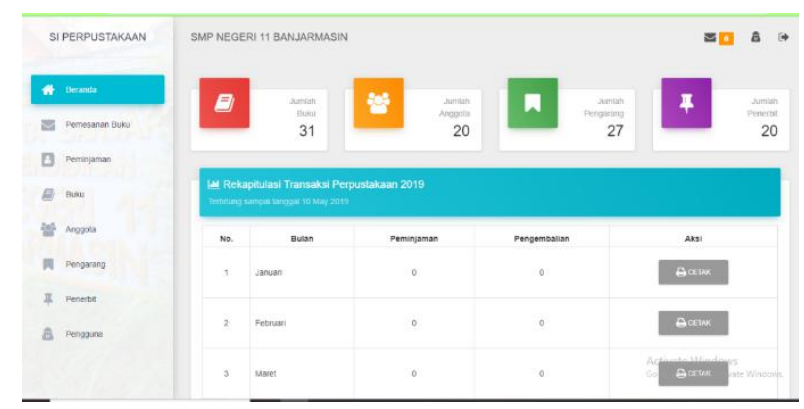

\section{KESIMPULAN}

Berdasarkan hasil yang dicapai dalam penelitian ini maka dapat disimpulkan bahwa Sistem Informasi Perpustakaan berbasis Web ini telah berhasil dirancang dan diimplementasikan, di mana terjadi peningkatan efisiensi dan efektivitas pada perpustakaan setelah mengimplementasikan sistem ini. Dengan adanya sistem informasi ini maka beberapa permasalahan pada sistem lama dimana yang masih menggunakan pencatatan buku pada transaksi peminjaman dan pengembalian buku, pengelolaan data buku, dan pengelolaan data anggota. dapat diatasi dengan baik oleh sistem baru.

\section{REFERENSI}

[1]. Amsyah, Zulkifli. (2005). Manajemen Sistem Informasi. Jakarta: Gramedia Pustaka Utama.

[2] Anhar. (2010). Panduan Menguasai PHP \& MySQL Secara Otodidak. Jakarta: mediakita.

[3] Bafadal, Ibarahim. (2008). Pengelolaan Perpustakaan Sekolah. Jakarta: Bumi Aksara.

[4] Hariadi, Fajar. (2013). Pembuatan Sistem Informasi Perpustakaan Pada SDN Sukoharjo Pacitan Berbasis Web. IJNS - Indonesian Journal on Networking and Security - ISSN: 2302-5700 http://ijns.org, 48-54.
[5] Hariyanto, Bambang. (2008). Dasar Informatika \& Ilmu Komputer. Yogyakarta: Graha Ilmu.

[6] Hidayat, Irwan; Saputra, M. Roesdi. (2015). Laporan Tugas Akhir Sistem Informasi Perpustakaan di SMP Negeri 5 Banjarmasin Berbasis Web Menggunakan Barcode. Banjarmasin: Politeknik Negeri Banjarmasin.

[7] Legowo, Antonius Indra. (2014). Sistem Informasi Perpustakaan Berbasis Website Dengan Menggunakan Barcode Scanner Pada SMK Negeri 3 Kendal. Universitas Dian Nuswantoro Semarang.

[8] Maryati, Kun; Suryawati, Juju. (2006). Sosiologi untuk SMA dan MA Kelas XII. Jakarta: Esis.

[9] Muslihudin, Muhammad; Oktafianto. (2016). Analisis dan Perancangan Sistem Informasi Menggunakan Model Terstruktur dan UML. Yogyakarta: ANDI.

[10] Mustakini, Jogiyanto Hartono. (2005). Sistem Teknologi Informasi. Yogyakarta: Andi.

[11] Nazir, Mohammad. (2014). Metode Penelitian. Bogor: Ghalia Indonesia.

[12] Nofriadi. (2015). Java Fundamental dengan NetBeans 8.0.2. Yogyakarta: Deepublish.

[13] Pawirosumarto, Suharno. (2008). Aplikasi Komputer. Jakarta: Mitra Wacana Media.

[14] http://lib.ui.ac.id/il/1 fungsi.jsp?hal=1

[15] https://www.ilmu-ekonomiid.com/2017/03/pengertian-barcodemanfaat-barcode-dan-jenis-jenisbarcode.html 